\title{
Alteration in Composition of Deoxyribonucleic Acid, Ribonucleic Acid, Proteins, and Amino Acids in Brain of Rats Fed High and Low Phenylalanine Diets
}

\author{
Salvador Castells ${ }^{[36]}$, Rosemarie Zischka, and Nicholas Addo \\ Department of Pediatrics, State University of New York Downstate Medical Center, Brooklyn, New York, USA
}

\section{Extract}

The effects of excess phenylalanine and deprivation of this amino acid on brain weight, ribonucleic acid (RNA), deoxyribonucleic acid (DNA), protein, and amino acid composition have been studied in the young rat.

Six-week-old male rats were fed for 2 weeks solid diets containing $0.26 \mathrm{~g} / 100 \mathrm{ml}$ phenylalanine (Phe controls), $7 \mathrm{~g} / 100 \mathrm{ml}$ phenylalanine (high Phe), and $0.06 \mathrm{~g} / 100$ $\mathrm{ml}$ phenylalanine (low Phe). Total brain RNA of rats fed the 7-g diet was $2.41 \pm 0.14$ $\mathrm{mg}($ mean $\pm \mathrm{sE}$ ), and total brain protein was $124.24 \pm 6.34 \mathrm{mg}$ (mean $\pm \mathrm{sE})$. Total brain RNA of controls was $3.62 \pm 0.17 \mathrm{mg}$ (mean $\pm \mathrm{sE}$ ), and total brain protein was $187.51 \pm 3.73 \mathrm{mg}($ mean $\pm \mathrm{sE})$. The brains of rats fed the 7 -g diet contained significantly less $(P<0.01)$ RNA and protein when compared with controls; DNA was not significantly changed. There was no significant diminution of the DNA, RNA, and protein content of brain in rats fed low amounts of Phe.

High levels of phenylalanine found in animals maintained for 2 weeks on the high phenylalanine diet were associated with increased amounts of phenylalanine and tyrosine and decreased amounts of valine, serine, threonine, methionine, isoleucine, and leucine in the brain. Low levels of phenylalanine found in animals fed low phenylalanine diets for 2 weeks were associated only with an increase in glycine content of the brain.

\section{Speculation}

The mechanisms of mental retardation associated with some inborn errors of amino acid metabolism are unknown. High levels of phenylalanine in blood coupled with altered amino acid composition of the brain may interfere with the mechanisms for synthesis of protein and RNA. It would seem appropriate to speculate that, since DNA levels remain constant in developed rat brain exposed to high phenylalanine diets, the derangement in the amino acid pool has an inhibitory effect on protein and RNA synthesis at the cytoplasmatic level. Altered brain protein and RNA synthesis may be of importance not only to central nervous system development in the neonatal period, but also to function in older phenylketonuric children. 


\section{Introduction}

It is probable that critical levels of phenylalanine in tissue are important for the normal functioning of the central nervous system. The high levels of phenylalanine found in blood and brain of phenylketonuric children (PKU) appear to produce severe brain damage, since a diet low in phenylalanine instituted during the first weeks of life permits nearly normal development [5]. Brain development is also affected in rats fed excessive quantities of L-phenylalanine $[15,26]$. Recent reports $[4,8,12]$ indicated that excessive depletion of phenylalanine retards growth and mental development of children and impairs the ability of rats to perform in behavior tests.

The biochemical changes characteristic of generalized amino acid deficiency (protein malnutrition) in rat brain have been extensively studied [27, 28], but the effects of excess or deficiency in one single amino acid have not been so well studied. The present paper reports the effects of diets high or low in phenylalanine on the amounts of DNA, RNA, protein, and amino acids in the brains of young rats.

\section{Materials and Methods}

Male rats of the Sprague-Dawley strain, approximately 6 weeks old (mean body weight at beginning of experiment $148.89 \pm 3.93 \mathrm{~g}$ sD), were given tap water ad libitum and caged in pairs in a room with controlled illumination (lights on from 6 AM to $6 \mathrm{PM}$ ). The rats were purchased for the experiment from a commercial supplier [30].

Rats were randomly allotted to groups. To maintain normal, high, and low phenylalanine levels in blood, a commercial preparation, Lofenalac [31], very low in L-phenylalanine content, but otherwise nutritionally complete was used. The chenical composition of $100 \mathrm{~g}$ Lofenalac powder is as follows (in g): total nitrogen, 2.4; fat, 18; carbohydrate, 57; minerals, 5; adequate amounts of vitamins and amino acids, with the exception of phenylalanine, which is present in the amount of $0.06 \mathrm{~g}$. When added, L-phenylalanine was first dissolved in hot water and then mixed with the powder in a blender [32].

\section{Experimental Groups}

Group $A$ (controls fed ad libitum): six rats were fed Lofenalac and L-phenylalanine was added $(0.26 \mathrm{~g} / 100$ $\mathrm{ml}$ ) to meet normal nutritional standards. Group $B$ (high L-Phe diet): six rats were fed Lofenalac and 7 $\mathrm{g} / 100 \mathrm{ml}$ of L-phenylalanine were added. Group $C$ (low L-Phe diet): six rats were fed Lofenalac without supplement of L-phenylalanine. Each group of experimental rats was fed ad libitum for 2 weeks. Since it is known that unbalanced amino acid mixtures produce a reduction in food intake [9], a second control group (pairfed controls) was fed the same amount of Lofenalac with $0.26 \mathrm{~g} / 100 \mathrm{ml}$ L-phenylalanine as was taken by both experimental groups.

\section{Biochemical Analysis}

The animals were killed by decapitation. Prior to death, blood was drawn by cardiac puncture to determine phenylalanine levels [18]. The brains were immediately removed with the medulla trimmed off. The remaining tissuc, including cerebellum, was used for determinations of amino acids, nucleic acids, and proteins.

Nucleic acids were extracted after homogenization of the brain in a salt solution ( $0.25 \mathrm{M}$ sucrose, $0.001 \mathrm{M}$ $\mathrm{MgCl}_{2}, 0.05 \mathrm{Mr} \mathrm{KCl}, 0.033 \mathrm{~N} \mathrm{CaCl}_{2}$, and 0.01 м Tris$\mathrm{HCl}, \mathrm{pH}$ 7) [20]. The RNA was determined by the orcinol reaction [13], DNA by the method of Ceriotti [6], and protein by the method of Lowry et al. [16]. To determine amino acid content, brain tissue was homogenized in $1 \%$ picric acid with 5 strokes at $10 \mathrm{sec}$ each of a motor-driven Teflon pestle. Samples were stored at $-20^{\circ}$ until the day of analysis. Amino acids were analyzed by the gradient elution column chromatography method of Spackman et al. [25] as modified by Piez and Morris [22] using an automatic amino analyzer [33]. The method did not resolve successfully the peaks for threonine and serine, and hence these are reported as a single value.

\section{Results}

The results (Table $\mathrm{I}$ ) indicate that high $\mathrm{L}$-phenylalanine intake (group B) causes high phenylalanine levels in both brain and blood. Brain weight in these animals was lower than in controls (group $A$ ). Body weight was also affected. The mean body weight of 96 $\mathrm{g}$ after 2 weeks of treatment was considerably below the initial body weight (mean: $148.89 \mathrm{~g}$ ) at the start of treatment, indicating that rats of group $B$ were severely intoxicated by the phenylalanine. A striking finding was the reduction of the total amount of brain RNA and protein in animals with high concentrations of phenylalanine in blood and brain. The DNA was not significantly changed. 
Table 1. Effects of high and low L-phenylalanil e (Phe) intake on brain composition of young rats ${ }^{1}$

\begin{tabular}{|c|c|c|c|c|c|c|c|c|c|c|}
\hline & \multirow{2}{*}{ Body wt, g } & \multirow{2}{*}{ Brain wt, $g$} & \multirow{2}{*}{$\begin{array}{c}\text { Food intake, } \\
\mathrm{g} / 24 \mathrm{hr}\end{array}$} & \multicolumn{2}{|c|}{ Phenylalanine } & \multicolumn{3}{|c|}{ Total brain content, $\mathrm{mg}$} & \multicolumn{2}{|c|}{ Ratio } \\
\hline & & & & $\begin{array}{c}\text { Blood, } \\
\mathrm{mg} / 100 \mathrm{ml}\end{array}$ & $\begin{array}{l}\text { Brain, } \\
\mathrm{mg} / 100 \mathrm{~g}\end{array}$ & DNA & RNA & Protein & $\frac{\mathrm{RNA}}{\mathrm{DNA}}$ & $\frac{\text { Protein }}{\text { DNA }}$ \\
\hline$A i^{2}$ & $204.7 \pm 4.62$ & $1.43 \pm 0.028$ & $22.7 \pm 1.44$ & $1.4 \pm 0.16$ & $0.97 \pm 0.16 s$ & $3.29 \pm 0.30 s$ & $3.31 \pm 0.11$ & $182.15 \pm 10.60 \mathrm{~s}$ & 1.00 & 55.36 \\
\hline$A i^{2}$ & $200.5 \pm 4.8$ & $1.40 \pm 0.08$ & 12.5 & $1.2 \pm 0.1$ & $0.89 \pm 0.14$ & $3.88 \pm 0.60$ & $3.62 \pm 0.17$ & $187.51 \pm 3.73$ & 0.93 & 48.32 \\
\hline$B$ & $96.4 \pm 3.1$ & $1.29 \pm 0.05$ & $12.3 \pm 1.3$ & $36.6 \pm 11.1$ & $9.4 \pm 2.7$ & $3.18 \pm 0.20$ & $2.41 \pm 0.14$ & $124.24 \pm 6.34$ & 0.75 & 39.06 \\
\hline $\begin{array}{l}C \\
A \text { vs } B \\
A \text { vs } C\end{array}$ & $\begin{array}{c}128.6 \pm 1.4 \\
P<0.018 \\
P<0.01\end{array}$ & $\begin{array}{c}1.35 \pm 0.03 \\
P<0.05 \\
P<0.05\end{array}$ & $\begin{array}{c}12.8 \pm 1.4 \\
P<0.01 \\
P<0.01\end{array}$ & $\mid \begin{array}{c}0.4 \pm 0.2 \\
P<0.01 \\
P<0.01\end{array}$ & $\begin{array}{c}0.85 \pm 0.03 \\
P<0.01 \\
\text { NS }\end{array}$ & $\begin{array}{c}3.12 \pm 0.22 \\
\text { NS } \\
\text { NS }\end{array}$ & $\begin{array}{c}3.13 \pm 0.07 \\
P<0.01 \\
\text { NS }\end{array}$ & $\begin{array}{c}155.82 \pm 13.88 \\
P<0.01 \\
\text { NS }\end{array}$ & 1.00 & 49.94 \\
\hline
\end{tabular}

1 Six a nimals were used in each group.

2 Ai: control group fed ad libitum. Aii: control group received the same amount and composition of food that experimental animals received (with exception of the aunino acid, L-Phe). There was no significant difference between both control groups. $B:$ group fed high $\mathrm{L}$-Phe diet. $C:$ group fed low $\mathrm{L}$-Phe diet.

Mean $\pm s e$.

- Mean $\pm \mathrm{sE}$ of average of 3 consecutive days' intake of individual rat.

- Mean $\pm \mathrm{sE}$ of average of two samples for the same animal.

- Probability (Student's $t$ test); NS = no significance.

Restriction of L-phenylalanine intake (group $C$ ) resulted in significantly low body and brain weights and in low phenylalanine levels in plasma. The content of phenylalanine in the brain was not significantly diminished after 2 weeks of restricted L-phenylalanine intake. The resistance of the brain to depletion of phenylalanine might explain why there were no significant changes in DNA, RNA, and protein content of the brain.

The high L-phenylalanine diet (group $B)$ led to significant increases in the levels of phenylalanine and tyrosine in brain, and significant reductions in the content of valine, methionine, isoleucine, and leucine in brain tissue. Serine and threonine, estimated together, were also decreased (Table II).

The restriction of L-phenylalanine (group C) produced only an increase in glycine content of the brain $(P<0.05)$ (Table II), but it did not produce changes in any of the other amino acids found in brain. Phenylalanine and tyrosine levels were not different from those found in controls.

\section{Discussion}

The changes in RNA and protein content found in brain of rats fed high phenylalanine diets seem to indicate that high phenylalanine diets affect protein and RNA metabolism in the central nervous system.

Cerebral protein synthesis appears to be particularly sensitive to changes in endogenous levels of amino acids [24, 29]. Mase et al. [17], in studies of amino acid incorporation into proteins of brain cortex slices, have arrived at similar conclusions. Evidence for adverse effects of low and high phenylalanine diets on protein synthesis during brain development have been pro- vided by the work of Dicrks-Ventling et al. [8]. They reported that when either diet was given to the mother rats during lactation and then the same diet to the wcanlings, a depletion in certain brain enzymes ensued, which could be explained as an advance effect on protein synthesis. Recently, clisaggregation of brain polyribosomes and decreased in vitro uptake of radioactive lysine have been reported in young rats receiving sufficient L-phenylalanine by intraperitoneal injection to cause hyperphenylalanemia [1].

In the present experiments, changes in RNA and protein metabolism took place at a time when the active period for RNA and protein synthesis was over

Table II. Effect of high and low phenylalanine (Phe) diets on concentration of amino acids in brain ${ }^{3}$

\begin{tabular}{|c|c|c|c|c|c|c|c|}
\hline \multirow{3}{*}{ Amino acid } & \multirow{2}{*}{\multicolumn{2}{|c|}{ Pair-fed controls }} & \multicolumn{5}{|c|}{ Phenylalanine } \\
\hline & & & \multicolumn{2}{|c|}{ High } & \multicolumn{3}{|c|}{ Low } \\
\hline & $22.9 \pm$ & 2.60 & $9.96 \pm$ & $2.01^{2}$ & 24.86 & \pm & 1.24 \\
\hline Glut & $44.0 \pm$ & 9.10 & $34.09 \pm$ & 0.76 & 51.35 & \pm & 23.06 \\
\hline Glut acid & $99.6 \pm$ & 11.10 & $110.15 \pm$ & 9.62 & 113.30 & \pm & 3.33 \\
\hline Gly & $7.75 \pm$ & 0.74 & $10.34 \pm$ & $0.56^{4}$ & 10.35 & \pm & $0.36^{4}$ \\
\hline Ala & $6.47 \pm$ & 0.49 & $5.02 \pm$ & 0.37 & 6.73 & \pm & 0.29 \\
\hline Val & $1.46 \pm$ & 0.21 & $0.44 \pm$ & 0.073 & 1.09 & \pm & 0.26 \\
\hline Met & $1.07 \pm$ & 0.13 & $0.21 \pm$ & $0.06^{2}$ & 2.34 & $\overline{ \pm}$ & 1.89 \\
\hline Iso & $0.49 \pm$ & 0.07 & $0.17 \pm$ & $0.01^{2}$ & 0.32 & \pm & 0.02 \\
\hline Leu & $1.12 \pm$ & 0.07 & $0.31 \pm$ & $0.08^{2}$ & 0.86 & \pm & 0.13 \\
\hline Tyr & $1.56 \pm$ & 0.19 & $10.58 \pm$ & $3.50^{\circ}$ & 2.27 & \pm & 0.96 \\
\hline Phe & $0.89 \pm$ & 0.14 & $9.40 \pm$ & $2.70^{\circ}$ & 0.85 & \pm & 0.03 \\
\hline Orn & $0.51 \pm$ & 0.06 & $0.40 \pm$ & 0.08 & 0.48 & \pm & 0.08 \\
\hline Lys & $3.69 \pm$ & 0.59 & $3.29 \pm$ & 0.31 & 3.32 & 土 & 0.17 \\
\hline llis & $0.96 \pm$ & 0.27 & $1.65 \pm$ & 0.18 & 1.64 & \pm & 0.15 \\
\hline Car & $1.55 \pm$ & 0.06 & $2.03 \pm$ & 0.34 & 1.66 & \pm & 0.06 \\
\hline Arg & $0.80 \pm$ & 0.14 & $0.78 \pm$ & 0.10 & 1.35 & \pm & 0.04 \\
\hline GABA & $40.08 \pm$ & 9.30 & $51.90 \pm$ & 10.53 & 50.47 & \pm & 5.37 \\
\hline
\end{tabular}

${ }^{1}$ Mean $\pm \mathrm{sE}$ (as $\mathrm{mg} / 100 \mathrm{~g}$ wet wt).

2 By our method, threonine and scrine were not separated, and the values are given together using the calculation factor for scrine.

- Significantly different at $<0.01$, columns two and three.

- Significantly different at $<0.05$, columns two and three. 
and after only 2 weeks of high t.phenylalanine intake. 'This is of interest, since it indicates that the toxicity of phenylalanine is not limited to the period of brain clevelopment. Barbato et al. [2] have reported no effects on rabbit brain RNA metabolism of high levels of phenylalanine sustained for $2.4 \mathrm{hr}$. The disagreement in results is probably due not only to the use of different experimental conditions and animals but also to the length of exposure to high intakes of phenylalanine.

The decreased food intake in the group fed high t.phenylalanine diets (group B) secms unlikely to be the caluse of low RNA and protein content of brain, since the low L-phenylalanine group (group $C$ ) had almost the same intake (with exception on the amount of t.-phenylalanine) as did the experimental phenylketonuric rats. The latter group did not manifest changes in $R N A$ and protein content in brain. The absence of changes in brain content of RNA and protein of the pair-fed controls provides further evidence of the specific toxicity of high phenylalanine diets on brain bio. chemistry. The lack of dillerences in DNA content (which might be considered to represent total britin cell number) could be related to the age of the rats when the experiments were done, since the most active period for brain DNA replication is over by 28 days.

The concentration of amino acids in brain is very sensitive to phenylalanine levels as shown by changes in the brain free amino acids content caused by a single injection of t.phenylalinine [3]. In our experiments, prolonged high levels of phenylalanine in plasma and correspondingly high concentration in the brain resulted in a pronounced increase in tyrosine in brain and in a significant depletion of cerebral pools of valine, methionine, isoletucine, and leucine. The combined value of serine and threonine was decreased in the high L-phenylalanine groups. These results are similar to the findings of .lokean et al. [19], who have also reported a significant depletion of cerebral pools of valine, methionine, isoleucine, leucine, and threonine after acute and chronic administration of L-phenylalianine to immature and mature rats.

Such specific patterns of change in the amino aciol pool of animals with high levels of phenylalanine in brain stands in contrast to the concept prevailing for so many years of an impenctrable blood-brain barrier for amino acids. "This concept was based on in vivo" experiments suggesting that the brain was slowly taking II) amino acids injected into the blood, when other tissues appeared to be able to take up amino acids readily.
Recently, Ford and Rhines [11] have presented data indicating that the uptake of certain amino acids by ventral horn neurons exceeds that seen in even such a metabolically active organ as the liver.

It would seem from the changes found in our studies that the mechanisms which influence the entry of amino acids into the brain are apparently amino acidspecific and are not relevant to the old concept of a static blood-brain barrier. Also the specific demands of a particular site in the brain [10] and the turnover of proteins into which the amino acids will be incorporated [14] are determining factors.

The pronounced increase in tyrosine values in brain is an important fincling considering the role of this amino acid in the synthesis of certain biogenic amines. Since the tyrosine intake of the hyperphenylalaninemic rats was almost $50 \%$ less than in controls (food intake was reduced by that amount), it would seem that tyrosine was coming from the hydroxylation of phenylalanine, although Rendina $c t$ al. [23] have also found increased levels of tyrosine in brain homogrchates of rats fed excesses of t.phenylalanine but with no increase in hepatic plienylalanine hydroxylase activity.

It has been found that the penetration of tyrosine into rat brain is markedly affected by other amino acids [7]. Neame [21] has observed during in vitro studies that tyrosine and phenylalanine share a carricr system, suggesting thit high levels of phenylalinine interfere with the transport of tyrosine into brain. Our finclings of high levels of tyrosine in brain seem to indicate that this may not be totally true in vivo. Thus, the proposal that mental retardation in children with PKU may be due to a depression in available tyrosine for amino synthesis appears to lack support.

Today, a diet with limited phenylalanine content constitutes the sole therapeutic strategy for children with PKU. Since Lofenalac is used for the treatment of phenylketonuria, it was of importance to see whether severe restriction of phenylalanine was able to produce changes in amino acids levels in brain. Low blood levels of phenylalanine appeared to be less damaging to the amino acid pool than high levels, failing to change the concentration of phenylalanine in brain and producing only an increase in glycine content.

The absence of changes in RNA, DNA, and protein in brain and a different pattern of altered amino acid composition in rats fed a low t-phenylalanine diet sug. gest that such a diet does not produce the same damag- 
ing effect in brain metabolism as does a high L-phenylalanine diet.

The changes reported with high t-phenylalanine administration occurred in rats at a time of completed brain development and only after 2 weeks of high phenylalanine levels in blood. If these findings can be related to children with $P K U$, it would seem to indicate that discontinuing the low L-phenylalanine diets and allowing elevated blood levels of phenylalanine might be harmful to the human brain at any age.

\section{Summary}

Total RNA, DNA, protein, and amino acid composition in brain has been studied in rats fed high and low phenylalanine intakes, and the results have been compared with controls.

The results indicated that rats initially fed a high phenylalanine dict at an age after complete brain maturation had developed show changes in amino acid composition of the brain. The content of RNA and protein in brain were diminished when compared with controls; levels of DNA were not significantly changed. A low phenylalanine diet did not produce any changes in DNA, RNA, and protein and only minor changes in amino acid composition in brain. Possible biological significance of these findings is discussed.

\section{References and Notes}

1. AOKI, K., AND SIfGre, F. L.: Hyperphenylalaninemia: Disaggregation of brain polyribosomes in young rats. Science, 168: 129 (1970).

2. Bakbato, L., Barbato, I. W. M., AND ILAMANAkA, A.: The in vivo effect of high levels of phenylalanine on lipids and RNA of the developing rabbit brain. Brain Res., 7: 399 (1968).

3. CARVER, M. T.: Influence of phenylalanine administration on the frec amino acids of brain and liver in the rat. J. Neurochem., 12: 45 (1965).

4. Casifilds, S., AND Brandr, I. K.: P'henylketonuria: Evaluation of therapy and verification of diagnosis. J. l'ediat., 72: 34 (1968).

5. Cintrekwall, W. R., Centerwat., S. A., Acosta, P. B., CunNoCk, R. F., ARMon, V., AND ManN, I. B.: Phenylketonuria. I. Dietary management of infants and young children. II, Results of treatment of infants and young children. J. Pediat., 59: 93 (1961).

6. Cr.кіottr, G.: A microchemical determination of deoxyribonucleic acid. J. Biol. Chem., 198: 292 (1952).

7. Cilikigos, M. A., Greengard, P., and Udenfriend, S.: Uptake of tyrosine by rat brain in vit'o. J. Biol. Chem., 235: 2075 (1960).

8. Difkes-Ventling, C., Wapie, R. A., and Braude, M. C.: Biochemical and behavioral effects of a commercial "low phenyl- alanine" diet in growing rats. Proc. Soc. Exp. Biol. Med., 127: 121 (1968).

9. ELI.ISON, J. S., AND KING, K. W.: MIcchanism of appetitc control in rats consuming imbalanced amino acid mixtures. J. Nutr., 9f: 543 (1968).

10. Fokd, D. H., Hartstein, M., ANd Ruodes, A.: The uptake of DI.-( $\left.{ }^{3} \mathrm{H}\right)$-lysinc into the nervous system as compared with other tissues in cuthyroid and dysthyroidal male rats. Acta Neurol. Scand., +1 : 215 (1965).

11. Ford, H., AND Rinnes, R.: Amino-acid uptake compared in motor neurons, spinal cord grey matter, muscle and liver. J. Neurol. Sci., 4: 501 (1967).

12. Hackney, I. M., Hanley, W. B., Davidson, W., and Linsao, L.: Phenylketonuria: Mental development, behavior, and termination of low phenylalanine diet. J. Pediat., 72: 646 (1968).

13. IIUtcinnson, W. C., and Munro, $H$. N.: The determination of nucleic acids in biological matcrials. Analyst, 86: 768 (1961).

14. IAjтиA, A.: Protein metabolism of the nervous system. Int. Rev. Neurobiol., 6: 1 (1964).

15. Loo, Y. II., Dillek, E., ANd OWen, J. E., JR.: Effect of phenylalanine diet on learning in the rat. Nature, 19f: 1286 (1962).

16. Iow'ry, O. R., Rosebrough, N. J., Fark, A. L., and Randal., R. J.: Protein measurement with the Folin phenol reagent. J. Biol. Chem., 193: 265 (1951).

17. Mase, K., Takahasui, Y., anu Ogata, K.: The incorporation of $\left({ }^{14} \mathrm{C}\right)$ glycine into the protein of guinea pig brain cortex slices. J. Neurochem., 9: 281 (1962).

18. McCaman, M. W., and Robins, E.: Fluorimetric method for the determination of phenylalanine in serum. J. Lab Clin. Med., 59: 885 (1962).

19. MrKean, C. M., Boggs, D. E., Ani Petfreson, N. A.: The influence of high phenylalanine and tyrosine on the concentrations of essential amino acids in brain. J. Neurochem., 15: 235 (1968).

20. Munko, II. N., AND Fleck, A.: Recent developments in the measurement of nucleic acids in biological materials. Analyst, 91: 78 (1966).

21. Neame, K. D.: Phenylalanine as inhibitor of transport of amino acid in brain. Nature, 192: 173 (1961).

22. Piez, K. A., AND Morkis, L.: A modified procedure for the automatic analysis of amino acids. Anal. Biochem., 1: 187 (1960).

23. Rendina, G., Ryan, M. F., De Long, J., Tuttle, J. M., and Git.rs, C. E.: Some biochemical consequences of fecding excesses of phenylalanine to rats. J. Ment. Defic. Res., 11: 153 (1967).

24. Ronerts, S., AND Morelos, B. S.: Regulation of ccrebral metabolism of amino acids. IV. Influence of amino acid levels on leucine uptake, utilization and incorporation into protein in vivo. J. Neurochem., 12: 373 (1965).

25. Spackman, D. H., Stein, W. H., and Moore, S.: Automatic recording apparatus for use in the chromatography of amino acids. Anal. Chem., 30: 1190 (1958).

26. WANG, H. L., and Waisman, II. A.: Experimental phenylketonuria in rats. Proc. Soc. Exp. Biol. Med., 108: 332 (1961).

27. Wivick, M., AND Nont.F, A.: Cellular response in rats during malnutrition at various ages. J. Nutr., 89: 300 (1966).

28. Winick, M., AND Noble, A.: Cellular response with increased fceding in neonatal rats. J. Nutr., $91: 179$ (1967).

29. Zomzely, C. E., RoberTs, S., aNd Rapaport, D.: Regulation of ccrebral metabolism of amino acids. III. Characteristics 
of amino acid incorporation into protein of microsomal and ribosomal preparations of rat cerebral cortex. J. Neurochem., 11: 567 (1964).

30. ARS Sprague Dawley, Madison, Wis.

31. Mcad Johnson Laboratories, Evansville, Ind.

32. Waring Products Division, Dynamics Corporation of America, New Hartford, Conn.

33. Phoenix Precision Instrument Division, VirTis Company, Gardiner, N. Y.
34. Supported by Public Health Service Research Grant no. MH 17104-01 from Mental Health Small Grant Section.

35. The authors would like to express their appreciation to Mead Johnson Laboratorics for providing the Lofenalac.

36. Requests for reprints should be addressed to: Salvador Castells, M.D., Department of Pediatrics, State University of New York Downstate Medical Center, 450 Clarkson Ave., Brooklyn, N. Y. 11203 (USA).

37. Accepted for publication October 8, 1970. 